\title{
Clustering of ingredients with amino acid composition similar to the nutritional requirement of Nile tilapia
}

\author{
Álvaro José de Almeida Bicudo ${ }^{1 \%}$; Luis Fernando Batista Pinto²; José Eurico Possebon \\ Cyrino $^{3}$ \\ ${ }^{1}$ UFRPE - Unidade Acadêmica de Garanhuns - Av. Bom Pastor, s/n - 55296-901 - Garanhuns, PE - Brasil. \\ ${ }^{2}$ UFBA/EMV - Depto. de Produção Animal - Av. Adhemar de Barros, 500 - 40170-110 - Salvador, BA - \\ Brasil. \\ ${ }^{3}$ USP/ESALQ - Depto. de Zootecnia, Setor de Piscicultura, C.P. 09 - 13418-900 - Piracicaba, SP - Brasil. \\ *Corresponding author < alvaro.bicudo@uag.ufrpe.br>
}

\begin{abstract}
The search for balanced diets, which may elicit improved growth of fish, requires appropriate selection of available protein sources. This study aims at clustering feedstuffs according to amino acid profile, determining which ones show essential amino acids (EAA) profiles closer to the ideal dietary amino acids requirements of Nile tilapia (Oreochromis niloticus), and studying the relationship among amino acids feedstuffs groups. Tabled data on EAA more cystine and tyrosine, in relation to lysine contents, of 40 feedstuffs ordinarily used to formulate fish diets were studied. Feedstuffs were grouped according to amino acids profile by cluster analysis of Euclidean distances. The principal components analysis was used to determine the relationship among amino acids in each feedstuff group. Three groups of ingredients were parted and two ingredients, low tannin sorghum and corn gluten meal 60\%, did not go with any group. Dietary amino acids requirements of Nile tilapia were similar to the amino acid profile of 22 feedstuffs. The principal component analysis explained with three principal components more than $75 \%$ of total variance of amino acids in three feedstuff groups. Therefore, until additional, detailed information on amino acids availability of different ingredients is consolidated, total amino acids profiles will continue to be important information to select and use conventional or surrogate ingredients for formulating and processing feeds for tilapia.

Key words: feedstuff, fish, multivariate analysis, nutrition, protein
\end{abstract}

\section{Agrupamento de ingredientes com composição de aminoácidos similar à exigência nutricional da tilápia do Nilo}

\begin{abstract}
RESUMO: A busca de uma ração balanceada, que proporcione maior crescimento aos peixes, passa pela escolha adequada das fontes protéicas disponíveis. Este estudo teve por objetivo agrupar alimentos de acordo com o perfil de aminoácidos essenciais, determinando quais mostram perfis mais próximos do requerimento da tilápia do Nilo (Oreochromis niloticus), e estudar a relação entre os aminoácidos dentro dos agrupamentos obtidos. Foram utilizadas composições de aminoácidos em relação ao conteúdo de lisina, de 40 alimentos comumente utilizados como ingredientes na formulação de dietas para peixes. Os ingredientes foram agrupados de acordo com o perfil de aminoácidos utilizando a análise de agrupamento por meio da distância Euclidiana, enquanto a análise de componentes principais foi utilizada para determinar a relação entre os aminoácidos em cada grupo obtido. Três grupos de ingredientes foram formados e apenas dois ingredientes, sorgo baixo tanino e farelo de glúten de milho 60\%, não entraram em nenhum dos três grupos. A exigência de aminoácidos da tilápia do Nilo foi semelhante ao perfil de aminoácidos encontrado em 22 alimentos. A análise de componentes principais conseguiu resumir e explicar $75 \%$ da variância total com apenas três componentes principais. Até que maiores informações sobre a disponibilidade de aminoácidos de diferentes ingredientes sejam obtidas, o perfil total de aminoácidos continuará a ser uma informação valiosa na escolha dos ingredientes a serem utilizados na formulação e processamento de alimentos para tilápia do Nilo.

Palavras-chave: alimentos, análise multivariada, nutrição, peixes, proteína
\end{abstract}

\section{Introduction}

Similarly to any other animal, Nile tilapia, Oreochromis niloticus, have no dietary requirement for protein, but actually require a well-balanced blend of essential (EAA) and nonessential amino acids (NEAA) in the diet (Santiago and Lovell, 1988; Furuya et al., 2004). When feed formulation is based on the ideal protein concept, smaller amounts of protein are used to meet dietary amino acid requirements of animals. Maximizing the effective use and minimizing the amount of dietary protein can substantially reduce production costs, increase farm profitability, and reduce excretion of nitrogenous wastes and fishing efforts to produce fishmeal (Wilson, 2002). Thus, identifying feedstuffs whose amino acid profiles equal or near fish dietary requirements can come handy for diets formulation and processing purposes. 
Cluster analysis is a multivariate procedure that seeks organizing information about variables so that relatively homogeneous groups or "clusters" can be formed (Johnson and Wichern, 1998). This analysis can group feedstuffs with amino acids contents which near dietary amino acids requirements of Nile tilapia. Additionally, principal component analysis can help to know the properties of each feedstuff cluster, because within each principal component, the original traits can be directly or indirectly correlated.

The present study aimed grouping feedstuffs according to amino acid profile and determining which ingredients are closer to Nile tilapia's AA profile, i.e. ideal protein, studying the relationship among amino acids in each of ingredients' group, as already done by Faria Filho et al. (2005) for the poultry industry, and finally, following the path set by Cravener and Rousch (2001), who used genetic algorithm to calibrate artificial neural networks to predict amino acid profiles in feed ingredients, demonstrating to fish nutritionists of both private and academic sector the use of an statistical tool to speed up the selection process of regionally available feedstuffs for fish feed formulation.

\section{Material and Methods}

Data on dry matter (DM), crude protein (CP) and total amino acid (AA) contents of selected feedstuff were obtained from NRC (1993) and Rostagno et al. (2005). Amino acid profiles (AAP) of feedstuffs were expressed as percent protein of each amino acid (dry matter basis) in relation to lysine (Table 1$)$, following the formula: $\mathrm{AAP}=100 \times \mathrm{EAA} /[\mathrm{Lys}]$, where EAA is the concentration of each amino acid, including cystine and tyrosine, in tilapia muscle tissue.

A vector representing the ideal AA profile for the nutrition of juvenile Nile tilapia was inserted in the data matrix, presenting the following composition (\% lysine): methionine + cystine (Met + Cys) 62.89\% , arginine (Arg) $82.03 \%$, leucine (Leu) 66.21\%, histidine (His) $33.59 \%$, phenylalanine + tyrosine (Phe + Tyr) 108.20\%, tryptophan ( $\operatorname{Trp}) 19.53 \%$, threonine (Thr) $73.24 \%$, isoleucine (Ile) 60.74\%, and valine (Val) 54.69\% (Santiago and Lovell, 1988). Lysine (Lys) was not added for it is the reference EAA (100\%).

For cluster analysis, the measure used to form the groups was the Euclidian distance, i.e. a symmetric distance, since a property of Euclidean space is that the distance from object $A$ to $B$ is the same as the distance from $B$ to $A$. The Euclidean distance between points $P=\left(p_{1}\right.$, $\left.p_{2, \ldots,} p_{n}\right)$ and $Q=\left(q_{1}, q_{2}, \ldots, q_{n}\right)$, in Euclidean $n$-space, is defined as:

$$
E D=\sqrt{\left(p_{1}-q_{1}\right)^{2}+\left(p_{2}-q_{2}\right)^{2}+\ldots+\left(p_{n}-q_{n}\right)^{2}}=\sqrt{\sum_{i=1}^{n}\left(p_{i}-q_{i}\right)^{2}}
$$

A hierarchical agglomerative algorithm was used to find successive clusters using previously established clusters. The agglomerative process begins with each ele- ment as a separate cluster and merges them into successively larger clusters. The traditional representation of this hierarchy is a tree called dendogram, with individual elements at one end and a single cluster containing every element at the other.

The principal components analysis transform an original group of $n$ standardized variable $\mathrm{x}_{\mathrm{i} 1}, \mathrm{x}_{\mathrm{i} 2}, \ldots, \mathrm{x}_{\mathrm{in}}$ in a new group $y_{i 1}, y_{i 2}, \ldots, y_{i n}$, that are linear functions of the $\mathrm{x}_{\mathrm{i} \text { 's }}$, already independent and with important properties (Johnson and Wichern, 1998).

$$
\begin{aligned}
& \text { Assuming that: } y_{i 1}=a_{11} x_{i 1}+a_{21} x_{i 2}+\ldots+a_{j 1} x_{i j} \\
& y_{i 2}=a_{12} x_{i 1}+a_{22} x_{i 2}+\ldots+a_{j 2} x_{i j} \\
& y_{i n}=a_{1 n} x_{i 1}+a_{2 n} x_{i 2}+\ldots+a_{j n} x_{i j}
\end{aligned}
$$

where: $y_{i n}$ is the score value of $\mathrm{n}^{\text {th }}$ principal component at $i^{\text {th }}$ feedstuff; $a_{i n}$ is the eigenvectors value for the $j^{\text {th }}$ amino acid at $\mathrm{n}^{\text {th }^{n}}$ principal component; and $X_{i j}$ is the value for $j^{\text {th }}$ amino acid at $i^{\text {th }}$ feedstuff, thus, if $y_{i 1}=a_{11} x_{i 1}$ $+a_{21} x_{i 2}+\ldots+a_{j 1} x_{i j}$ is the first principal component for $i^{t h}$ feedstuff and $y_{i 2}=a_{12} x_{i 1}+a_{22} x_{i 2}+\ldots+a_{i 2} x_{i j}$ is the second principal component for the $i^{\text {th }}$ feedstuff, then the more important properties are: (i) $\sum a_{j 1}^{2}=\sum a_{j 2}^{2}$ and $\sum a_{j 1} a_{j 2}=0$ (principal components are independents), and (ii) among the principal components, $Y_{i 1}$ have the largest variance; $Y_{i 2}$ the second largest, and so on.

The criterion of minimum variance equal to $75 \%$ was used for selection the number of principal components. The eigenvalues and eigenvectors were estimates of the matrix of correlation according to Johnson and Wichern (1998).

\section{Results and Discussion}

The cluster analysis was used herein to group feedstuffs according to similar amino acid composition. The dendrogram obtained with cluster analysis is presented in Figure 1. The dashed line showed the point used to analyze the clustering. Three groups of feedstuffs were parted, and only two ingredients (low tannin sorghum and corn gluten meal $60 \%$ ) did not go with any group up to the dashed line point. From top to bottom in the dendrogram: Group 1 (G-1) is formed by the feedstuffs gelatin, meat and bone meals 35, 45 and $60 \%$ crude protein (CP), condensed fish solubles, blood meal, fish meals 54 and 60\% CP, alcohol yeast, casein, poultry by-product meal, poultry by-product high oil meal, shrimp condensed process residue meal, canola meal, micronized soybean, soy protein concentrate, extruded soy, roasted whole soybean, soybean meals 45 and $48 \% \mathrm{CP}$ and crab meal process residue, Nile tilapia EAA profile - i.e. dietary requirements included; Group 2 (G-2) is formed by feather and poultry by-product meal, rice bran, defatted rice bran, wheat bran, high lysine corn, wheat middlings, cottonseed meal 39\% CP, sunflower meal solvent extracted, and peanut meal; Group 3 (G-3) comprises the feedstuffs 
Table 1 - Feedstuff composition.

\begin{tabular}{|c|c|c|c|c|c|c|c|c|c|c|c|c|}
\hline \multirow[b]{2}{*}{ Ingredients } & \multicolumn{12}{|c|}{ Composition(\%) } \\
\hline & $\mathrm{DM}^{1}$ & $\mathrm{CP}^{2}$ & Lys & Arg & His & Ile & Leu & $\begin{array}{c}\text { Met }+ \\
\text { Cys }\end{array}$ & $\begin{array}{c}\text { Phe }+ \\
\text { Tyr }\end{array}$ & Thr & $\operatorname{Trp}$ & Val \\
\hline cohol yea & 90.85 & 36.75 & 8.33 & 58.17 & 27.78 & 64.05 & 3.46 & 29.74 & 80.72 & 71.90 & 16.34 & 74.84 \\
\hline blood meal** & 2.79 & 82.80 & .08 & 46.01 & 67.15 & 9.31 & 145.48 & 24.20 & 113.03 & 55.19 & 19.41 & 97.47 \\
\hline brewers yeast $* *$ & 87.36 & 42.60 & 8.57 & 60.27 & 26.85 & 68.77 & 88.49 & 29.04 & 88.22 & 64.38 & & 65.21 \\
\hline canola me & .54 & 37.58 & .40 & 116.75 & 49.26 & 78.82 & 131.03 & 80.79 & 111.82 & 7.83 & 3.65 & 91.13 \\
\hline Casein** & 91.35 & 84.21 & 8.24 & 44.24 & 35.01 & 66.43 & 107.64 & 42.80 & 137.03 & 54.61 & 15.56 & 81.56 \\
\hline Corn $* *$ & .11 & 8.26 & 2.91 & 162.50 & 108.33 & 120.83 & 5.00 & 150.00 & 291.67 & 133.33 & 29.17 & 166.67 \\
\hline corn disti & 91.00 & 27.00 & 2.41 & 172.31 & 98.46 & 167.69 & 44.62 & 147.69 & 366.15 & 150.77 & 15.38 & 230.77 \\
\hline corn $\mathrm{gl}$ & 87.93 & 21.10 & 2.61 & 158.18 & 129.09 & 118.18 & 347.27 & 158.18 & 221.82 & 140.00 & 23.64 & 194.55 \\
\hline corn $\mathrm{g}$ & 90.95 & 60.35 & 1.66 & 196.00 & 129.00 & 255.00 & 1050.00 & 246.00 & 727.00 & 210.00 & 31.00 & 285.00 \\
\hline corn, 1 & 88.43 & 8.26 & 4.24 & 145.71 & 88.57 & 74.29 & 208.57 & 94.29 & 162.86 & 97.14 & 31.43 & 128.57 \\
\hline cotton & 89.99 & 39.45 & 4.16 & 271.95 & 70.12 & 83.54 & 5.73 & 78.05 & 199.39 & 82.93 & 31.10 & 114.02 \\
\hline crab $\mathrm{m}$ & 92.00 & 31.40 & 4.39 & 120.29 & 35.51 & 84.78 & 1.59 & 55.80 & 168.84 & 72.46 & 1.01 & 106.52 \\
\hline ffat & 89.60 & 15.50 & 4.45 & 163.77 & 57.97 & 78.26 & 159.42 & 86.96 & 155.07 & 84.06 & 27.54 & 118.84 \\
\hline tru & 90.47 & 37.00 & 6.03 & 121.52 & 44.39 & 76.23 & & 48.43 & 143 & 65 & & 79.82 \\
\hline & 91.52 & 65.50 & 4.34 & 157.39 & 41.55 & 99.30 & 175.35 & 98.59 & 184.51 & 98.94 & 19.72 & 135.92 \\
\hline & 90.71 & 83.90 & 2.86 & 232.08 & 47.08 & 163.33 & & 168.75 & 271.67 & 160.83 & 24.17 & 250.00 \\
\hline fish $\mathrm{m}$ & 92.26 & 54.40 & 6.27 & 100.59 & 32.55 & 67.45 & & 8.91 & 113.49 & 68.62 & .20 & \\
\hline fish $n$ & 91.63 & 61.10 & 7.10 & 86.87 & 30.65 & 58.06 & 102.07 & 52.53 & 101.61 & 58.53 & & 70.51 \\
\hline & 50.00 & 32.70 & 5.69 & 84.95 & 87.10 & $41.4 C$ & & 48.39 & 70.97 & 46 & & 65.59 \\
\hline & 3.00 & 87.60 & 4.05 & 196.34 & 20.00 & 38. & & 24.23 & & 50 & & \\
\hline $\mathrm{w} \tan$ & 87.97 & 9.23 & 2.17 & 175.00 & 105.00 & 185.00 & 600.00 & 160.00 & 480.00 & 155.00 & 5.00 & 235.00 \\
\hline meat an & 92.65 & 35.40 & 4.72 & $160-16$ & 29.94 & 47.90 & 106.59 & 41.92 & 98.80 & 59.28 & 8.38 & 80.84 \\
\hline & 92.90 & 44.54 & 4.92 & 151.60 & 37.44 & 51.14 & 120.09 & 45.21 & 108.68 & 62.10 & 10.96 & 84.93 \\
\hline 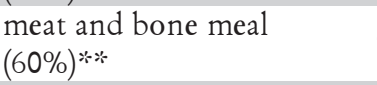 & 94.07 & 60.10 & 5.16 & 130.97 & 36.77 & 52.58 & 113.23 & 43.87 & 105.48 & 59.68 & 11.94 & 85.81 \\
\hline ed couhern** & 92.62 & 39.14 & 6.21 & 125.93 & 46.09 & 76.95 & 127.98 & 45.68 & 140.74 & 61.73 & .99 & 80.66 \\
\hline peanut me & 89.55 & 48.45 & 3.24 & 338.22 & 71.34 & 104.46 & 195.54 & 70.70 & 266.24 & 80. & 36.94 & 124. \\
\hline & & 13.1 & 0 & & & & & & & & & 68 \\
\hline & 93.90 & 55.30 & 5.59 & 126.21 & 34.63 & 66.99 & 125.89 & 59.55 & 120.06 & 69.90 & 16.83 & 86.41 \\
\hline by-product meal*** & & 57.00 & & & & & & & & & & \\
\hline rice $b$ & 89.30 & 13.24 & 4.76 & 158.73 & 53.97 & 74.60 & 152.38 & 82.54 & 155.56 & 77.78 & 25.40 & 112.70 \\
\hline rice, brok & 88.04 & 8.47 & 3.31 & 210.71 & 64.29 & 125.00 & 246.43 & 135.71 & 275.00 & 96.43 & 39.29 & 157.14 \\
\hline roasted $\mathrm{w}$ & 90.27 & 37.00 & 6.03 & 121.52 & 44.39 & 76.23 & & & 143.50 & 65.92 & & 79.82 \\
\hline testaue & 88.00 & 39.90 & 5.44 & 108.29 & 41.47 & 67.28 & 119.82 & 64.98 & 140.09 & 65.44 & 19.35 & 84.33 \\
\hline soy protein concentrate ${ }^{* *}$ & 89.88 & 62.92 & 6.47 & 130.71 & & 74.2 & & 46.68 & & 63.88 & & 78.13 \\
\hline & & 45.32 & 6.11 & & & 75.81 & & & & & & 77.98 \\
\hline soybean meal $(48 \%)^{* * *}$ & 88.21 & 47.90 & 6.10 & 119.86 & 44.18 & 75.34 & 124.32 & 46.92 & 140.75 & 63.70 & 21.92 & 78.77 \\
\hline meal, solvent & 93.00 & 40.70 & 4.08 & 216.87 & 57.83 & 118.07 & 164.46 & 94.58 & 171.08 & 96.99 & 36.75 & 156.63 \\
\hline wheat bran** & 88.00 & 15.52 & 3.99 & 172.58 & 69.35 & 80.65 & 154.84 & 93.55 & 159.68 & 82.26 & 37.10 & 116.13 \\
\hline & & 12.26 & 2.45 & & & 160.00 & & & & 116.67 & & 166.67 \\
\hline wheat midlings** & 88.17 & 13.61 & 3.38 & 145.65 & 69.57 & 104.35 & 193.48 & 108.70 & 193.48 & 91.30 & 91.30 & 130.43 \\
\hline
\end{tabular}

*Data from NRC (1993). ** Data from Rostagno et al. (2005). ${ }^{1}$ Dry matter. ${ }^{2}$ Crude protein. 


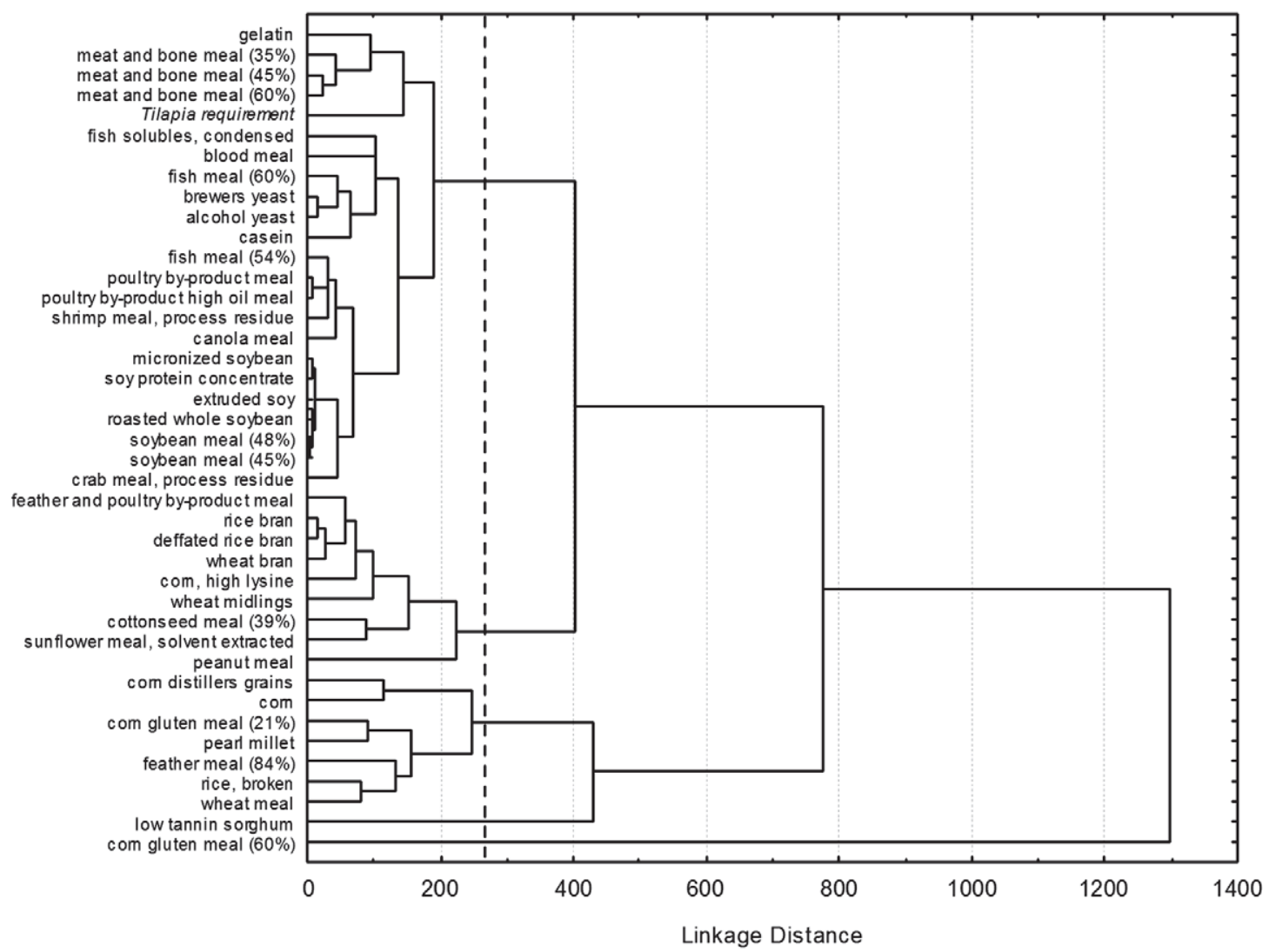

Figure 1 - Dendrogram of the Euclidian distances among ingredients.

corn distillers grains, corn, corn gluten meal $21 \%$ CP, pearl millet, feather meal $84 \%$, broken rice, and wheat meal.

The dendogram was obtained using multitrait information of the nine essential amino acids. Thus, results are more reliable than single information to evaluate which feedstuffs hold higher similarity with Nile tilapia EAA profile, so nearing the species dietary requirement. Dietary amino acids requirements of Nile tilapia were similar to amino acid profiles of 22 of the analyzed feedstuff (G-1); corn gluten meal 60\% was the ingredient holding the lowest similarity.

All G-1 feedstuff can be potentially used to formulate feeds targeting tilapia's ideal protein, that is, ideal amino acids profile. Feedstuff with amino acids profile closer to that of Nile tilapia's dietary requirements were gelatin and meat and bone meals (35, 45 and 60\% of crude protein, respectively) (Figure 1). This confirms observations of Pezzato et al. (2002), who reported that meat and bone meals are protein sources of higher biological value $(73.2 \%)$ than that of fish meal for Nile tilapia, and can replace up to $100 \%$ of fish meal in diets for the species (El-Sayed, 1998). As a matter of fact, because of the high quality and availability of their nutrients for different fish species (Hardy and Barrows, 2002), Nile tilapia included (Santiago and Lovell, 1988), gelatin and casein are actually known as standard protein sources for purified and semi-purified diets (NRC, 1993).
Regarding plant protein sources, canola meal was the ingredient whose amino acid profile was closer to tilapia dietary requirements (Figure 1). Actually, dose-response studies have demonstrated that canola meal is an adequate protein source for aquafeeds (Furuya et al., $2001 \mathrm{~b}$ ), and do not affect growth performance when included from $24 \%$ (Gaiotto et al., 2004) to 51\% (Souza et al., 2004) on diets of Nile tilapia at different phases of the growth cycle. Canola meal can replace up to $48 \%$ of dietary soybean meal protein in feeds without affecting growth performance of fingerling tilapia (Soares et al., 2001). Soybean meal is the chief plant protein source for aquafeeds (Watanabe, 2002). According to cluster analysis, other soybean by-products have amino acids profiles more similar to fish ideal protein and can also can be included in aquafeeds, provided restrictions regarding the presence of anti-nutritional factors in some these products are observed (Francis et al., 2001).

For analyzing each group resulting from cluster analysis it is proposed the use of principal component analysis (Table 2). This analysis allows not only simplify the variance in few canonical variables using eigenvalue information, but also checks the relation between different AA using eigenvector coefficients.

For all groups defined by the cluster analysis, the principal component analysis abridged the information of nine amino acids on three principal components that together can explain more than $75 \%$ of total variance. Ideally, the total variance should be reduced to two prin- 
cipal components which would explain more than $80 \%$ of the total variance, because it should be easier explaining the results in a bi-dimensional dimension; however, abridging the variance for three principal components i.e. the adjustment of analysis - is considered adequate.

Eigenvectors that can be used to build the equation for each principal component in each of groups are showed in Table 3. For instance, the first principal component in the G-1 can be represented by the following equation:

$" \mathrm{PC} 1=0.07(\mathrm{Arg})-0.06(\mathrm{His})-0.68(\mathrm{Ile})-0.78(\mathrm{Leu})-$ 0.67 (Met + Cys) -0.85 (Phe+ Tyr) $-0.77($ Thr $)-0.86($ Trp $)$ $-0.74(\mathrm{Val})$ ”.

Each feedstuff has a PC1 value that depends on its amino acid contents and larger eigenvectors indicate higher importance of a given amino acid for the PC1 value. In addition, eigenvectors can also be used to explain associations among the nine amino acids studied, given that within each principal component, amino ac- ids with different eigenvectors signs are negatively correlated; otherwise, they are directly correlated.

Regarding G-1, the first principal component (CP1) explain the variance of the amino acids Ile, Leu, Met + Cys, Phe+Tyr, Thr, Trp, and Val (Table 3), because the eigenvectors for those traits had the largest values; since all those amino acids present negative signals for the eigenvectors, they are directly associated. Only His and Arg did not have important eigenvectors for $\mathrm{CP} 1$ and their variances are explained by the components CP2 and CP3, respectively. Therefore, Arg and His can thus be either in excess or shortage in processed tilapia feeds, if either fish meal or surrogate protein sources, such as brewer's yeast, gelatin, casein, alcohol yeast, etc. are used (Table 1). Dietary requirements of Arg and His of fish range on $4-5 \%$ and $1.5-2.5 \%$ of dietary protein, respectively (Wilson, 2002). Arginine deficiencies result in reduced growth and nitrogen retention (Tibaldi et al., 1994; Ruchimat et al., 1998). However, as metabolization of glutamate can make up for

Table 2 - Principal components with eigenvalues larger than one.

\begin{tabular}{|c|c|c|c|c|c|c|}
\hline & \multicolumn{2}{|c|}{ Group 1} & \multicolumn{2}{|c|}{ Group 2} & \multicolumn{2}{|c|}{ Group 3} \\
\hline & Eigenvalue & Cumulative & Eigenvalue & Cumulative & Eigenvalue & Cumulative \\
\hline & & $\%$ & & $\%$ & & $\%$ \\
\hline PC1 & 4.14 & 45.96 & 3.24 & 36.01 & 3.44 & 38.27 \\
\hline PC2 & 1.79 & 65.85 & 2.56 & 64.49 & 2.44 & 65.39 \\
\hline PC3 & 1.01 & 77.06 & 1.69 & 83.24 & 1.34 & 80.31 \\
\hline
\end{tabular}

PC - Principal components. Group 1 - gelatin, meat and bone meals 35, 45 and 60\% crude protein (CP), condensed fish solubles, blood meal, fish meals 54 and $60 \% \mathrm{CP}$, alcohol yeast, casein, poultry by-product meal, poultry by-product high oil meal, shrimp condensed process residue meal, canola meal, micronized soybean, soy protein concentrate, extruded soy, roasted whole soybean, soybean meals 45 and 48\% CP and crab meal process residue. Group 2 - feather and poultry by product meal, rice bran, deffated rice bran, wheat bran, high lysine corn, wheat middlings, cottonseed meal 39\% CP, sunflower meal solvent extracted, and peanut meal. Group 3 - corn distillers grains, corn, corn gluten meal 21\% CP, pearl millet, feather meal 84\%, broken rice, and wheat meal.

Table 3 - Eigenvectors of principal components with eigenvalues larger than one.

\begin{tabular}{|c|c|c|c|c|c|c|c|c|c|}
\hline \multirow{2}{*}{$\begin{array}{l}\text { Amino } \\
\text { Acids }\end{array}$} & \multicolumn{3}{|c|}{ Group 1} & \multicolumn{3}{|c|}{ Group 2} & \multicolumn{3}{|c|}{ Group 3} \\
\hline & PC1 & PC2 & PC3 & PC1 & PC2 & PC3 & PC1 & PC2 & PC3 \\
\hline Arg & 0.07 & 0.59 & -0.70 & -1.06 & 0.54 & -2.10 & 0.24 & -0.84 & 0.32 \\
\hline His & -0.06 & -0.84 & -0.07 & 2.11 & -0.43 & 0.13 & 0.02 & 0.91 & 0.30 \\
\hline Ile & -0.68 & 0.52 & 0.39 & 0.89 & 1.40 & 0.23 & 0.30 & -0.33 & -0.80 \\
\hline Leu & -0.78 & -0.33 & -0.35 & -1.54 & 0.51 & 1.72 & 0.57 & 0.75 & -0.19 \\
\hline Met + Cys & -0.67 & 0.21 & -0.10 & 1.63 & -3.57 & -0.15 & 0.52 & -0.27 & 0.58 \\
\hline Phe + Tyr & -0.85 & -0.06 & -0.05 & 1.80 & 1.65 & 0.35 & 0.50 & 0.03 & -0.34 \\
\hline Thr & -0.77 & 0.41 & 0.15 & -2.11 & -0.76 & 1.84 & 0.92 & 0.04 & 0.01 \\
\hline $\operatorname{Trp}$ & -0.86 & -0.31 & 0.27 & 0.78 & 1.20 & -0.49 & -0.87 & -0.25 & -0.15 \\
\hline $\mathrm{Val}$ & -0.74 & -0.21 & -0.36 & -2.49 & -0.54 & -1.53 & 0.92 & -0.31 & -0.02 \\
\hline
\end{tabular}

PC - Principal components. Group 1 - gelatin, meat and bone meals 35, 45 and 60\% crude protein (CP), condensed fish solubles, blood meal, fish meals 54 and 60\% CP, alcohol yeast, casein, poultry by-product meal, poultry by-product high oil meal, shrimp condensed process residue meal, canola meal, micronized soybean, soy protein concentrate, extruded soy, roasted whole soybean, soybean meals 45 and $48 \%$ CP and crab meal process residue. Group 2 - feather and poultry by product meal, rice bran, deffated rice bran, wheat bran, high lysine corn, wheat middlings, cottonseed meal 39\% CP, sunflower meal solvent extracted, and peanut meal. Group 3 - corn distillers grains, corn, corn gluten meal 21\% CP, pearl millet, feather meal 84\%, broken rice, and wheat meal. 
circa $33 \%$ of fish Arg requirements (Buentello and Gatlin, 2000), using ingredients moderately deficient in Arg but with adequate levels of glutamic acid in aquafeeds, do not affect growth performance of fish.

Histidine is involved in metabolic functions such as production of histamines and osmoregulation; it also plays a role on the production of energy for use in other metabolic pathways during certain emergencies or stressful conditions (Abe and Ohmama, 1987). Dietary deficiency of His cause poor growth, low feed efficiency, cataract, increased mortality and incidence of lordosis (Breck et al., 2003); on the other hand, excess in dietary His decrease the growth rate and feed efficiency (Ravi and Devaraj, 1991; Murthy and Varghese, 1995; Ahmed and Khan, 2005).

With regard to feedstuffs of G-2, variance of some amino acids profiles and contents are not explained by only one principal component. For instance, Leu has eigenvectors with important values in CP1 and CP3. Such results reveal a complex relationship among the amino acids profile G-2 feedstuffs. However, the Euclidean distance between G-1 and G-2 is smaller than between the G-1 and G-3 (Figure 1).

In G-3, eigenvectors are almost similar to G-1; however, not only Leu, Met +Cys, Phe+Tyr, Thr, and Val have negative relationship with $\operatorname{Trp}$, but also Ile do not present correlations with those amino acids of G-1. The CP2 explains the negative association between His and Arg, that is, within ingredients of G-3 the largest values of His correspond to lowest values of Arg. The CP3 explains the variance of Ile, and only in this group Ile is not associated with other amino acid.

In conclusion, selection and use of feedstuffs in aquafeeds cannot be based only on price range; the quality of the protein, i.e. amino acids profile and availability, will determine the efficiency of nitrogen deposition on carcass (Engin and Carter, 2005), and as a consequence, the economics of diets and production. To date, only a few feedstuffs were appraised in regard to availability of their amino acids contents for tilapia (Fagbenro, 1998; Köprücü and Özdemir, 2005; Furuya et al., 2001 a; Henry-Silva et al., 2006; Guimarães et al., 2008 a, b). Cluster and principal component analysis showed to be an interesting tool to identify potential protein sources for fish diets according to EAA requirements. However, total amino acids profile will remain a key information to guide selection and use of feedstuffs in the production of processed tilapia feeds, because chemical composition of feedstuffs vary to a great extent and that certainly influences the nutrients digestibility.

\section{Acknowledgements}

To Fundação de Amparo à Pesquisa do Estado de São Paulo (FAPESP) for granting the Doctoral and the Post-Doctoral scholarship for the first and the second authors, respectively (protocols 05/51968-9 and 07/507362). The third author is a CNPq scholar.

\section{References}

Abe, H.; Ohmama, S. 1987. Effect of starvation and sea-water acclimation on the concentration of free L-histidine and related dipeptides in the muscle of eel, rainbow trout and Japanese dace. Comparative Biochemistry and Physiology 88: 507-511.

Ahmed, I.; Khan, M.A. 2005. Dietary histidine requirement of fingerling Indian major carp, Cirrbinus mrigala (Hamilton). Aquaculture Nutrition 11: 359-366.

Breck, O.; Bjerkas, E.; Campbell, P.; Arnesen, P.; Haldorsen, P.; Waagbo, R. 2003. Cataract preventative role of mammalian blood meal, histidine, iron and zinc in diets for Atlantic salmon (Salmo salar L.) of different strains. Aquaculture Nutrition 9: 341-350.

Buentello, J.A.; Gatlin III, D.M. 2000. The dietary arginine requirement of channel catfish (Ictalurus punctatus) is influenced by endogenous synthesis of arginine from glutamic acid. Aquaculture 188: 311-321.

Cravener, T.L.; Rousch, W.B. 2001. Prediction of amino acids profiles in feed ingredient: genetic algorithm calibration of artificial neural networks. Animal Feed Science and Technology 90: 131-141.

El-Sayed, A.F.M. 1998. Total replacement of fishmeal with animal protein sources in Nile tilapia Oreochromis niloticus (L.), feeds. Aquaculture Research 29: 275-280.

Engin, K.; Carter, C.G. 2005. Fish meal replacement by plant and animal by-products in diets for the Australian short-finned eel, Anguilla australis australis (Richardson). Aquaculture Research 36: $445-454$

Fagbenro, O.A. 1998. Apparent digestibility of various legume seed meals in Nile tilapia diets. Aquaculture International 6: 83-87.

Faria Filho, D.E.; Torres, K.A.A.; Campos, D.M.B.; Vieira, B.S.; Urbano, T.; Rosa P.S.; Ferraudo, A.S. 2005. Ingredient classification according to the digestible amino acid profile: an exploratory analysis. Brazilian Journal of Poultry Science 7: 185-193.

Francis, G.; Makkar, H.P.S.; Becker, K. 2001. Antinutritional factors present in plant-derived alternate fish feed ingredients and their effects in fish. Aquaculture 199: 197-227.

Furuya, W.M.; Pezzato, L.E.; Barros, M.M.; Pezzato, A.C.; Furuya, V.R.B. 2004. Use of ideal protein concept for precision formulation of amino acid levels in fish-meal-free diets for juvenile Nile tilapia (Oreochromis niloticus L.). Aquaculture Research 35: 1110-1116.

Furuya, W.M.; Pezzato, L.E.; Pezzato, A.C.; Barros, M.M.; Miranda, E.C. 2001a. Digestibility coefficients and digestible amino acids values of some ingredients for Nile tilapia (Oreochromis niloticus). Revista Brasileira de Zootecnia 30: 11431149. (in Portuguese, with abstract in English).

Furuya, W.M.; Pezzato, L.E.; Miranda, E.C.; Furuya, V.R.B.; Barros, M.M.; Lanna, E.A.T. 2001b. Apparent nutrient and energy digestibility of canola meal for Nile tilapia (Oreochromis niloticus) Revista Brasileira de Zootecnia 30: 611-616. (in Portuguese, with abstract in English).

Gaiotto, J.R.; Macedo-Viegas, E.M.; Fernandes, T.R. 2004. Canola meal for juvenile Nile tilapia, Chitralada strain. Acta Scientiarum 26: 15-19. (in Portuguese, with abstract in English).

Guimarães, I.G.; Pezzato, L.E.; Barros, M.M. 2008a. Amino acid availability and protein digestibility of several protein sources for Nile tilapia, Oreochromis niloticus. Aquaculture Nutrition 14: 396-404

Guimarães, I.G.; Pezzato, L.E.; Barros, M.M.; Tachibana, L. 2008b. Nutrient digestibility of cereal grain products and by-products in extruded diets for Nile tilapia. Journal of the World Aquaculture Society 39: 781-789.

Hardy, R.W.; Barrows, F.T. 2002. Diet formulation and manufacture. p. 505-600. In J.E. Halver; Hardy, R.H., eds. Fish nutrition. 3ed. Academic Press, New York, NY, USA. 
Henry-Silva, G.G.; Camargo, A.F.M.; Pezzato, L.E. 2006. Apparent digestibility of aquatic macrophytes by Nile tilapia (Oreochromis niloticus) and water quality in relation nutrient concentrations. Revista Brasileira de Zootecnia 35: 641-647. (in Portuguese, with abstract in English).

Johnson, R.A.; Wichern, D.W. 1998. Applied Multivariate Statistical Analysis. 4ed. Prentice Hall, Upper Saddle River, NJ, USA.

Köprücü, K.; Özdemir, Y. 2005. Apparent digestibility of selected feed ingredients for Nile tilapia (Oreochromis niloticus). Aquaculture 250: 308-316.

Murthy, H.S.; Varghese, T.J. 1995. Arginine and histidine requirement of the Indian major carp, Labeo rohita. Aquaculture Nutrition 1: 235-239.

National Research Council [NRC]. 1993. Nutrient Requirements of Fish. National Academic Press, New York, NY, USA.

Pezzato, L.E.; Miranda, E.C.; Barros, M.M.; Pinto, L.G.Q.; Furuya, W.M.; Pezzato, A.C. 2002. Apparent digestibility of feedstuffs by Nile tilapia (Oreochromis niloticus). Revista Brasileira de Zootecnia 31: 1595-1604.

Ravi, J.; Devaraj, K.V. 1991. Quantitative essential amino acid requirements for growth of catla, Catla catla (Hamilton). Aquaculture 96: 281-291.

Rostagno, H.S.; Albino, L.F.T.; Donzele, J.L.; Gomes, P.C.; Oliveira, R.F.; Lopes, D.C.; Ferreira, A.S.; Barreto, S.L.T. 2005. Brazilian Table for Poultry and Pigs: Food Composition and Nutritional Requirements. Editora da UFV, Viçosa, MG, Brazil. (in Portuguese).
Ruchimat, T.; Masumoto, T.; Yoshiaki, I.; Shimeno, S. 1998. Quantitative arginine requirement of juvenile yellow tail (Seriola quinqueradiata). Fisheries Science 64: 348-349.

Santiago, C.B.; Lovell, R.T. 1988. Amino acids requirements for growth of Nile tilapia. The Journal of Nutrition 118: 1540-1546.

Soares, C.M.; Hayashi, C.; Faria, A.C.E.A.; Furuya, W.M. 2001. Replacement of soybean meal protein by canola meal protein in diets for Nile tilapia (Oreochromis niloticus) in the growing phase. Revista Brasileira de Zootecnia 30: 1172-1177. (in Portuguese, with abstract in English).

Souza, S.R.; Hayashi, C.; Galdioli, E.M.; Soares, C.M.; Meurer, F. 2004. Different protein vegetal sources for the Nile tilapia (Oreochromis niloticus L.) during sexual reversion. Acta Scientiarum 26: 21-28.

Tibaldi, E.; Tulli, F.; Lanari, D. 1994. Arginine requirement and effect of different dietary arginine and lysine levels for fingerling sea bass (Dicentrarchus labrax). Aquaculture 127: 207-218.

Watanabe, T. 2002. Strategies for further development of aquatic feeds. Fisheries Science 68: 242-252.

Wilson, R.P. 2002. Amino acids and proteins. p. 143-179. In: Halver, J.E.; Hardy, R.W., eds. Fish Nutrition. 3ed. Academic Press, San Diego, CA, USA.

Received August 26, 2009

Accepted May 14, 2010 